УДК 579.017

\title{
Effect of Orientation on Properties of Ultrafine Fibers Produced \\ by Electrostatic Molding \\ from Poly-3-Hydroxybutyrate
}

\author{
Dmitriy B. Goncharov ${ }^{\mathrm{a}}$ and Aleksey G. Sukovatyi ${ }^{\mathrm{b} *}$ \\ ${ }^{a}$ Siberian Federal University \\ 79 Svobodny, Krasnoyarsk, 660041, Russia \\ ${ }^{b}$ Institute of Biophysics SB RAS \\ 50/50 Akademgorodok, Krasnoyarsk, 660036, Russia
}

Received 21.04.2014, received in revised form 18.05.2014, accepted 05.06.2014

Using the method of electrostatic molding from poly-3-hydroxybutyrate solutions, non-oriented and oriented ultrathin fibers (UF) and forming non-woven matrices were produced, and their properties were studied. After measuring the physical-mechanical characteristics of the products obtained by the ESM method, a positive effect of orientation on the strength properties (Young's modulus and tensile strength), porosity and vapor permeability was revealed.

Keywords: polyhydroxyalkanoates, electrostatic molding, physical-mechanical properties.

(c) Siberian Federal University. All rights reserved

* Corresponding author E-mail address: a.sukovatiy@ya.ru 


\title{
Влияние ориентированности
}

\author{
на свойства ультратонких волокон, \\ полученных методом \\ электростатического формования \\ из поли-3-гидроксибутирата
}

Д.Б. Гончарова

${ }^{a}$ Сибирский федеральный университет

Россия, 660041, Красноярск, пр. Свободный, 79

${ }^{6}$ Институт биофизики СО РАН

Россия, 660036, Красноярск, Академгородок, 50/50

С использованием метода электростатического формования из растворов поли-3гидроксибутирата получены неориентированные $и$ ориентированные ультратонкие волокна (УВ), формирующие нетканые матриксы, и исследованы их свойства. Результать измерения физико-механических характеристик ЭСФ-изделий показали положительное влияние ориентированности на прочностные свойства (модуль Юнга и прочность на разрыв), пористость, паропроницаемость.

Ключевые слова: полигидроксиалканоаты, электростатическое формование, физикомеханические свойства.

\section{Введение}

Метод электростатического формования (ЭСФ), или электроспиннинг, является одним из многообещающих процессов в области производства нетканых материалов и матриксов из-за своей простоты, высокой производительности и потенциала использования в различных сферах (Huang et al., 2003). Метод ЭСФ основан на использовании высокого электрического напряжения для формования ультратонких волокон из полимерного раствора или расплава через капилляр тонкого диаметра. Техника электроспиннинга зависит от ряда параметров, включая тип полимеров и свойства раствоpa (например, вязкость, поверхностное натяжение и проводимость), конфигурацию процесса (напряженности электрического поля, скорости подачи раствора, диаметра иглы, расстояния между наконечником иглы и основанием коллектора) (Sill et al., 2008). Поэтому изменение одного или всех параметров влияет на размер волокон, их форму и морфологию. Управляя параметрами процесса, можно получить волокна согласно поставленным задачам. Кроме того, изменение структурных особенностей, таких как диаметр, пористость, механические свойства и т. п., в свою очередь, играет существенную роль в биомедицинском использовании ЭСФ изделий, например в клеточной и тканевой инженерии, т. к. от их структуры значительно зависит адгезия, пролиферация, дифференцировка и рост клеток (Liu et al., 2013). 
Использование метода на базе изученных характеристик применительно к конкретному типу полимера позволяет получить волокна с диаметрами в диапазоне от 100 до 500 нм, которые называют нановолокнами (Liu et al., 2012; Li et al., 2013; Li et al., 2009).

С развитием нанотехнологий к процессу электростатического формования интерес возрос из-за высокого потенциала применения в таких областях, как тканевая инженерия, системы контролируемой доставки лекарств, фильтрация и защитная одежда.

Типичная установка для ЭСФ состоит из капилляра, через который подаётся полимерный раствор с последующим вытягиванием в волокно, источника высокого напряжения, который заряжает струю, и заземленного коллектора (Sill et al., 2008). Для подачи жидкости сквозь капилляр обычно используется шприцевой насос, гравитационные силы и газ под давлением. Электрод от источника высокого напряжения погружают в жидкость или прикрепляют непосредственно к капилляру, если он металлический. Увеличение напряжения электрического поля вызывает отталкивание между однополярными зарядами в жидкости, и силы притяжения между противоположно заряженными раствором и коллектором оказывают растягивающие усилие в жидкости, удлиняя каплю на кончике капилляра, в результате формируется нить (Теo et al., 2006). Напряжение электрического поля при дальнейшем увеличении достигает той точки, при которой баланс поверхностного натяжения жидкости приводит к развитию конуса Тейлора (Yarin et al., 2001). При дальнейшем преодолении данной величины напряжения происходит образование струи из вершины конуса, которая стремится к собирающему коллектору. В то время как струя ускоряется в направлении к коллектору, она хаотически нестабильно изгибается, тем самым увеличивая время и длину пути к коллектору, способствуя испарению растворителя (Lannutti et al., 2007).

В зависимости от задач могут быть использованы различные конфигурации коллекторов, включая неподвижную пластину, вращающийся барабан, растворитель (например, вода) и т. д. Как правило, использование стационарного коллектора приводит к образованию хаотически ориентированного волокнистого матрикса. Вращающийся коллектор может быть использован для создания материала с ориентированными волокнами. Скорость вращения коллектора влияет на степень выравнивания, ее увеличение приводит к формированию хорошо выровненных волокон, что, в свою очередь, оказывает влияние на физико-механические свойства получаемых нетканых мембран (Chew et al., 2005).

Необходимо отметить, что диаметр ультратонких волокон является одним из самых важных свойств, регулируемых параметрами электростатического формования, поскольку волокна с диаметрами в нанометровом диапазоне точно имитируют структуру белков во внеклеточном матриксе. Эта характеристика имеет такое же важное значение, как и размер, масштаб и рельеф, так как играет важную роль в клеточной пролиферации и адгезии (Flemming et al., 1999). Кроме того, нетканые волокнистые матриксы имеют очень высокую долю площади по отношению к объёму, что при взаимодействии с клетками значительно повышает их прикрепляемость (Xu et al., 2004).

Следующим важным параметром нетканого материала является пористость, характеризующая способность транспортировки питательных веществ к клеткам. На данный момент многие исследователи столкнулись 
с ограничениями в отношении клеточной инфильтрации на матах из-за относительно небольших пор в материале. Для преодоления данных ограничений используют дополнительные методы модификации нетканых мембран, такие как выщелачивание, смешанный электроспиннинг и увеличение диаметра волокон (Zhu et al., 2008). Возможность проектирования нетканых матриксов с порами желаемого размера для лучшей клеточной инфильтрации и ангиогенеза позволяет материалу активнее включаться в окружающие ткани.

Механические свойства нетканых мембран чрезвычайно важны при использовании изделий в качестве носителей клеток в тканевой инженерии. Механическими свойствами можно управлять, варьируя состав раствора, а также изменяя параметры обработки. Данный факт должен приниматься во внимание при изготовлении матриксов для реконструктивных технологий.

Освоение метода ЭСФ применительно к природным полиэфирам - полигидроксиалканоатам (ПГА) начато сравнительно недавно. Техника ЭСФ для этого класса полимеров впервые опробована нашим коллективом на примере растворов поли-3-гидроксибутирата и сополимеров 3-гидроксибутирата с 3-гидроксивалератом с использованием авторской лабораторной установки (Гордеев и др., 2005). Влияние параметров процесса (диаметр капилляра, расстояние между мишенями, напряжение электрического поля) на диаметр и характеристики ультратонких волокон, получаемых из полимера 3-гидроксимасляной кислоты (П(ЗГБ)), было изучено в работе (Гончаров и др., 2012); было показано, что с увеличением плотности полимерного раствора возрастает диаметр волокон, повышается их эластичность на фоне некоторого снижения прочности.
В настоящее время количество работ, направленных на переработку ПГА методом ЭСФ, возрастает (Yu et al., 2012; Wang et al., 2012; Masaeli et al., 2013). Показано, что свойства ЭСФ изделий зависят как от химического состава полимеров, так и параметров формования. Одним из важных параметров процесса ЭСФ, существенно влияющих на структуру и прочностные характеристики волокон, является тип принимающей мишени и возможность ориентирования волокон.

Это определило цель настоящей работы, направленной на изучение влияния ориентированности волокон на их структуру и физико-механические свойства.

\section{Материалы и методы}

Исследованы высокоочищенные образцы П(ЗГБ) со следующими характеристиками: средневесовая молекулярная масса 1200 кДа; полидисперсность 1,66; степень кристалличности 76 \%; температура плавления и температура термической деградации 179,0 и $294,8^{\circ} \mathrm{C}$ соответственно.

Для получения ультратонких волокон методом ЭСФ использована установка Nanon 01A («MECC Inc.», Япония). Полимерный раствор (концентрация 5 мол. \%) помещали в пластиковый шприц с внутренним диаметром 13 мм. Процесс проводили при следующих параметрах: скорость подачи раствора 5 мл/ч; напряжение 25 кВ; расстояние между электродами 15 см. В качестве собирающей мишени для получения неориентированных или ориентированных волокон использовали, соответственно, плоскую стальную пластину или крутящийся барабан (скорость вращения 1000 об/мин).

Морфологию и диаметр ультратонких волокон анализировали на сканирующем электронном микроскопе («Hitachi HТ Corporation», Япония) при напряжении 5 и 
15 кВ. Предварительно образцы напыляли золотом (10 мА, 40 c) с помощью установки вакуумного напыления Emitech K575X. Свойства поверхности образцов изучали на базе измерения краевых углов смачивания водой, величину которых регистрировали на приборе Drop Shape Analyzer DSA25E (KRÜSS GmbH) с программным обеспечением LabDesk ${ }^{\mathrm{TM}}$. Толщину изделий измеряли цифровым микрометром LEGIONER EDM25-0.001 (Германия). Физико-механические свойства изучали с использованием универсальной испытательной машины Instron 5565, 5KN (Instron, Великобритания) при комнатной температуре. Исследовали гантелеобразные образцы длиной 50 мм, шириной 6,1 мм и толщиной 25-30 мкм. Длина зажима образцов составляла 30 мм, скорость ползуна 3 мм/мин. Предварительно изготовленные образцы выдерживали при нормальных условиях в течение двух недель до достижения равновесия кристаллизации. Для каждого типа изделий испытано не менее пяти образцов. Измерения проводили при комнатной температуре; регистрировали модуль Юнга (Е, МПа), прочность на разрыв ( $\sigma$, МПа) и удлинение при разрыве $(\varepsilon, \%)$, используя программное обеспечение Bluehill 2 (Elancourt, Франция). Модуль Юнга определялся для каждой кривой напряжениедеформация в области упругой деформации. Погрешность измерения не превышала $10 \%$.

Паропроницаемость образцов (Water vapor transmission rates (WVTR) $\left(\Gamma \cdot \mathrm{M} / \mathrm{M}^{2} \cdot\right.$ сут.)) определяли на установке Mocon Permatran W 3/31 (Миннеаполис, Миннесота, США). Площадь образцов составляла 5 см² $^{2}$ температура измерения $37,8{ }^{\circ} \mathrm{C}$. Для сравнения значений WVTR для различных образцов полученные данные были нормированы на толщину (Tsuji et al., 2006; Shogren, 1997; Modi, 2011). Пористость (П, \%) измеряли на основании методики, приведенной в работе (Li et al., 2008).
Статистическую обработку результатов проводили с использованием стандартного пакета программы Microsoft Excel. Оценивали средние значения и ошибки среднего. Достоверность отличия средних значений в контрольных и экспериментальных группах проверяли в зависимости от величины выборки по U-критерию Манна-Уитни и t-критерию Стьюдента (уровни значимости: 0,05 и 0,01 ).

\section{Результаты и обсуждение}

На рис. 1 представлены РЭМ-снимки неориентированных и ориентированных ультратонких волокон (УВ), полученных из растворов П(ЗГБ) в хлороформе с использованием различных принимающих мишеней. На ориентированных волокнах, собранных с помощью барабанной мишени, в отдельных случаях имели место небольшие дефекты в виде незначительного слипания волокон. Однако в целом полученные образцы были хорошего качества и пригодны для исследования структуры поверхности, физико-механических и биологических свойств.

Средний диаметр неориентированных волокон составил 2,98 мкм (диапазон распределения от 1,0 до 3,5 мкм). Средний диаметр ориентированных волокон был ниже - 2,06 мкм. При этом диапазон распределения диаметра волокон равнялся 2 мкм. Толщина ЭСФ матриксов, сформированных ориентированными волокнами, составила 25-30 мкм, что сопоставимо с этим параметром у неориентированных волокон.

Ориентация волокон оказывала влияние на физико-механические характеристики ЭСФ изделий (табл. 1). Для ориентированных образцов, полученных методом ЭСФ, показано значительное увеличение прочностных характеристик. Так, показатели прочности у неориентированных волокон, оцениваемые по величине модуля 

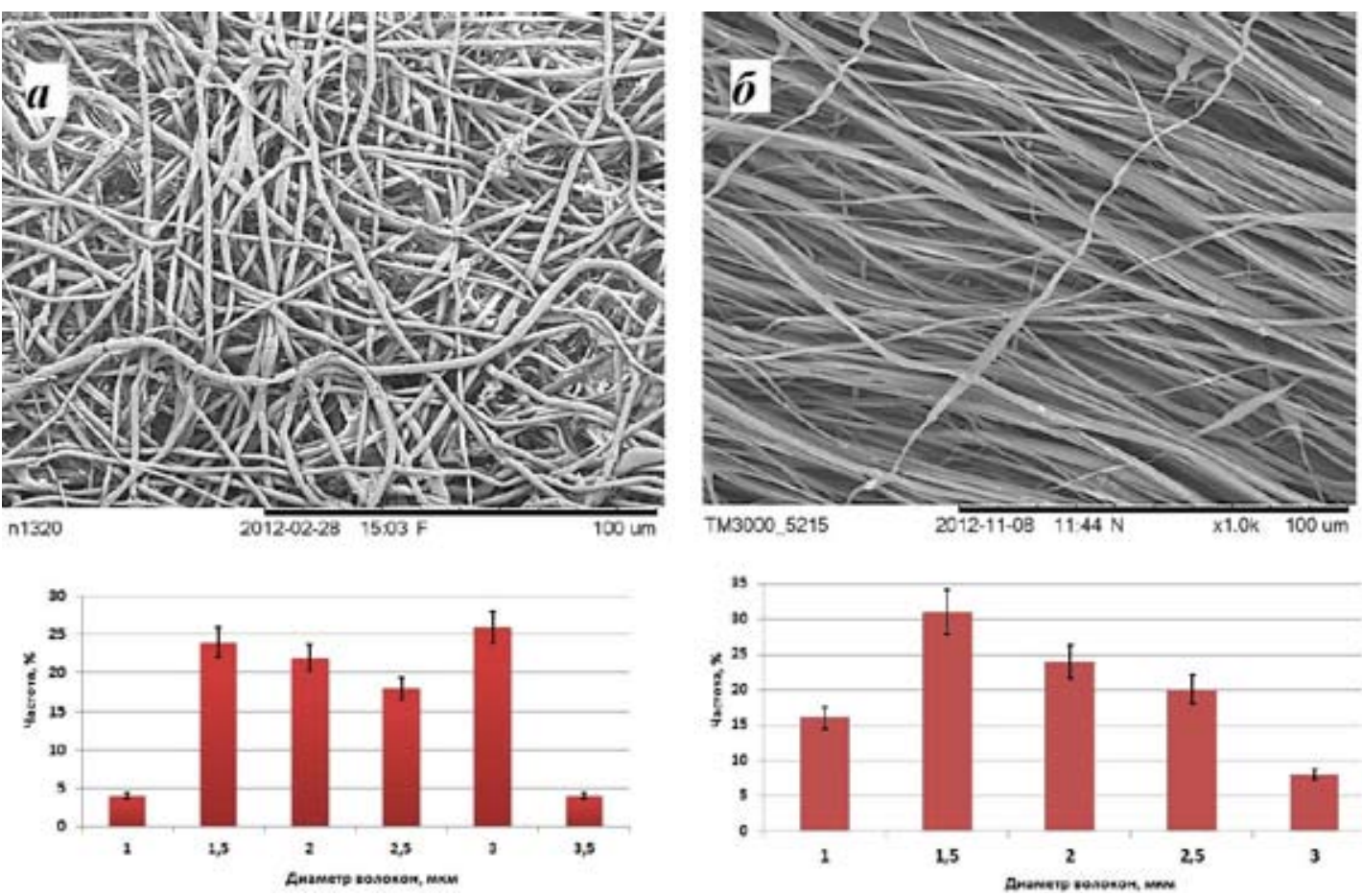

Рис. 1. РЭМ-снимки и распределение диаметра волокон нетканых матриксов, образованных неориентированными (а) и ориентированными (б) ультратонкими волокнами из П(ЗГБ)

Таблица 1. Физико-механические характеристики неориентированных и ориентированных ультратонких волокон, полученных из П(ЗГБ)

\begin{tabular}{|c|c|c|c|c|c|c|}
\hline Образец & 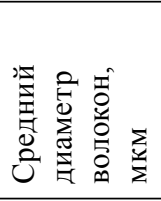 & 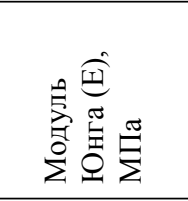 & 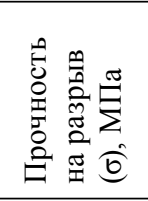 & 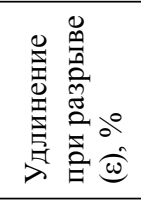 & 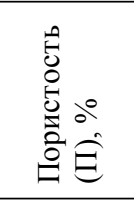 & 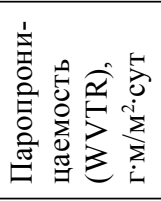 \\
\hline Неориентированный & 2,98 & $16,23 \pm 4,62$ & $0,32 \pm 0,07$ & $13,3 \pm 3,11$ & $73,3 \pm 6,2$ & $7517,6 \pm 560$ \\
\hline Ориентированный & 2,06 & $162,03 \pm 32,45$ & $6,17 \pm 2,33$ & $9,90 \pm 3,21$ & $79,2 \pm 5,8$ & $9494,6 \pm 610$ \\
\hline
\end{tabular}

Юнга и разрывной прочности, составили $16,23 \pm 4,62$ и 0,32 $\pm 0,07$ МПа соответственно, а удлинение при разрыве (показатель эластичности) $13,3 \pm 3,11 \%$. Образцы с ориентированными УВ в отличие от неориентированных имели более высокие значения показателей механической прочности, у них модуль Юнга и разрывная прочность равнялась $162,03 \pm 32,45$ и $6,17 \pm 2,33$ МПа соответственно при близкой величине удлинения

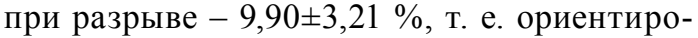
ванность волокон практически не влияла на эластичность матриксов П(ЗГБ).

Влияние ориентированности волокон зарегистрировано при исследовании пористости и паропроницаемости ЭСФ изделий. Так, для неориентированных УВ эти параме-

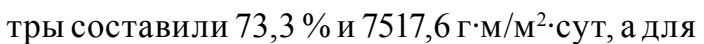
ориентированных - 79,2 \% и 9494,6 г·м/м²·сут соответственно (табл. 1). 

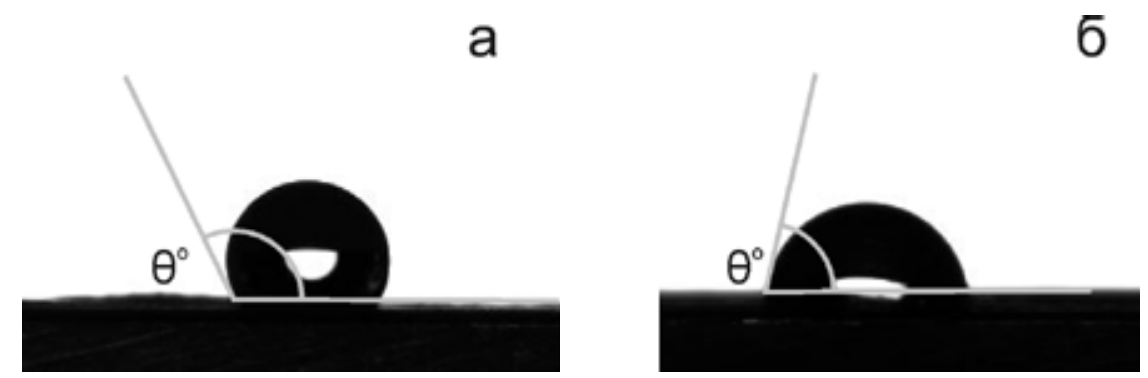

Рис. 2. Снимки краевых углов смачивания водой на матриксах, образованных неориентированными (а) и ориентированными (б) ультратонкими волокнами из ПЗ(ГБ)

Матриксы, образованные неориентированными УВ, имели значение краевого угла смачивания водой, косвенно характеризующего гидрофильность, равное $123,9 \pm 2,4^{\circ}$ (рис. 2), для ориентированных волокон эта величина составила $85,9 \pm 5,6^{\circ}$.

Физико-механические испытания обоих типов нетканых мембран из ПЗГБ показали выраженное влияние времени хранения на физико-механические свойства материала.

На рис. 3 приведена временная зависимость физико-механических характеристик ориентированных (рис. 3а) и неориентированных (рис. 3б) образцов. Для ориентированных нетканых мембран по истечении 60 сут хранения модуль Юнга увеличился в 5 раз - до 812,18 МПа, а напряжение при разрыве в 2,2 раза - до 13,92 МПа. Аналогичные изменения основных механических параметров отмечены и для неориентированных нетканых мембран. По истечении 60 сут модуль Юнга повысился до 85,58 МПа (соответственно в 5,3 раза), а напряжение при разрыве - в 7,2 раза (от 0,24 до 1,73 МПа). При этом необходимо отметить, что изменение удлинения при разрыве для обоих типов оставалось в пределах погрешности измерений. Данный факт свидетельствует о повышении механической прочности изделий из ПЗГБ.

Таким образом, изменение физикомеханических характеристик с течени- ем времени происходит вне зависимости от структурной ориентации мембран из П(ЗГБ), что свидетельствует о процессах, происходящих в самой структуре полимера. Похожие результаты были получены и описаны в работе G. J. M. de Koning и Р. J. Lemstra (1992). В основе данных изменений лежит явление прогрессирующей кристаллизации полимерной структуры, а не перегруппировки кристаллов. Сравнительно небольшая потеря аморфной фракции и прогрессирующая кристаллизация серьезно ограничивают аморфную фазу и, следовательно, способствуют изменению механических характеристик.

\section{Заключение}

В рамках проведённого исследования изучены физико-механические свойства неориентированных и ориентированных ультратонких волокон, формирующих нетканые матриксы и полученных с использованием метода электростатического формования из растворов поли-3-гидроксибутирата. На основании имеющихся результатов установлена временная зависимость прочностных свойств изделий из ПЗГБ и показано положительное влияние структурной ориентации ультратонких волокон как на прочностные свойства, так и на величину пористости и паропроницаемости матриксов. 

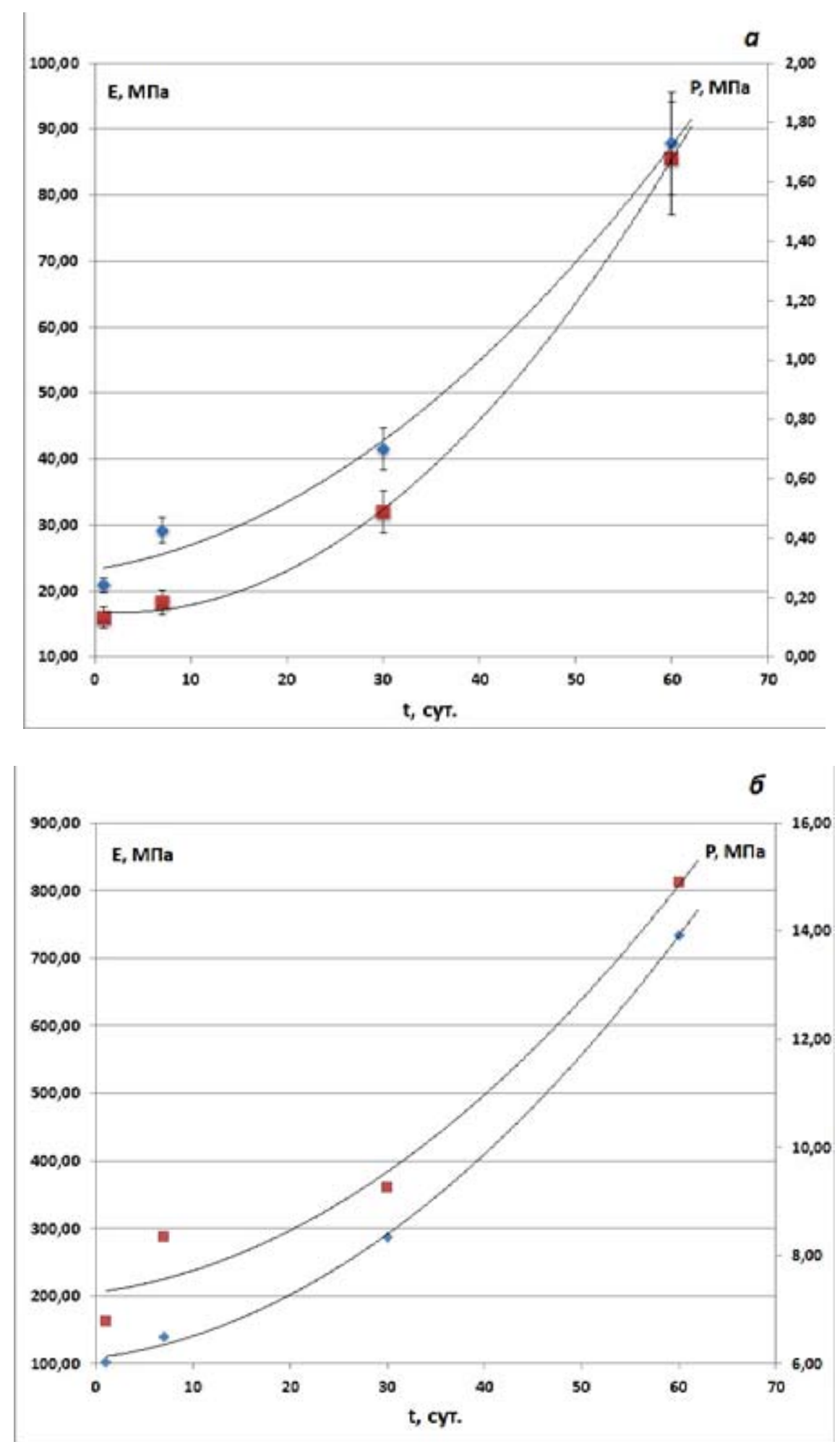

Рис. 3. Временная зависимость физико-механических характеристик ориентированных (а) и неориентированных (б) образцов нетканых мембран из ПзГБ: '/" - модуль Юнга, разрыве 


\section{Список литературы}

1. Гончаров Д.Б., Николаева Е.Д., Суковатый А.Г., Шабанов А.В., Шишацкая Е.И., Маркелова Н.М. (2012) Характеристики ультратонких волокон, полученных методом электростатического формования из поли-3-гидроксибутирата. Журнал СФУ. Серия Биология 5 (4): 417426.

2. Гордеев С.А., Шишацкая Е.И., Волова Т.Г. (2005) Получение и исследование ориентированных волокон из полимеров поли(гидроксибутирата-гидроксивалерата). Перспективные материалы. 3: 50-55.

3. Chew S.Y., Wen J., Yim E.K., Leong K.W. (2005) Sustained release of proteins from electrospun biodegradable fibers. Biomacromolecules. 6 (4): 2017-2024.

4. de Koning G. J. M., Lemstra P. J. (1993) Crystallization phenomena in bacterial poly[ ( R)-3- hyd roxybutyrate]: 2. Embrittlement and rejuvenation. POLYMER 34: 4089-4094

5. Flemming R.G., Murphy C.J., Abrams G.A., Goodman S.L., Nealey P.F. (1999) Effects of synthetic micro- and nano-structured surfaces on cell behavior. Biomaterials. 20 (6): 573-588.

6. Formhls A. (1939) Method and apparatus for spinning. United States patent US 2,169,962

7. Huang Z.M., Zhang Y.Z., Kotaki M., and Ramakrishna S. (2003) A review on polymer nanofibers by electrospinning and their applications in nanocomposites. Composites Science and Technology. 63 (15): 2223-2253.

8. Lannutti J., Reneker D., Ma T., Tomasko D. and Farson D. (2007) Electrospinning for tissue engineering scaffolds. Materials Science and Engineering . 27 (3): 504-509.

9. Li X. M., Wang L., Fan Y. B., Feng Q. L., Cui F. Z., and Watari F. (2013) Nanostructured scaffolds for bone tissue engineering. Journal of Biomedical Materials Research A. 101 (8): 2424-2435.

10. Li X. T., Zhang Y., Chen G. Q. (2008) Nanofibrous polyhydroxyalkanoate matrices as cell growth supporting materials. Biomaterials 29: 3720-3728

11. Li X., Gao H., Uo M. (2009) Effect of carbon nanotubes on cellular functions in vitro. Journal of Biomedical Materials Research A. 9 (11): 132-139.

12. Li X., Liu H., Niu X. (2012) The use of carbon nanotubes to induce osteogenic differentiation of human adipose-derived MSCs in vitro and ectopic bone formation in vivo. Biomaterials. 33 (19): 4818-4827.

13. Liu H., Ding X., Zhou G., Li P., Wei X., and Fan Y. (2013) Electrospinning of Nanofibers for Tissue Engineering Applications. Journal of Nanomaterials. 2013: 11 p.

14. Sill T. J. and von Recum H. A. (2008) Electrospinning: applications in drug delivery and tissue engineering. Biomaterials. 29 (13): 1989-2006.

15. Teo W. E. and Ramakrishna S. (2006) A review on electrospinning design and nanofibre assemblies. Nanotechnology. 17 (14): 89-106.

16. Xu C., Inai R., Kotaki M., and Ramakrishna S. (2004) Electrospun nanofiber fabrication as synthetic extracellular matrix and its potential for vascular tissue engineering. Tissue Engineering. 10 (8): 1160-1168.

17. Yarin A. L., Koombhongse S., and Reneker D. H. (2001) Bending instability in electrospinning of nanofibers. Journal of Applied Physics. 89 (5): 3018-3026.

18. Zhu X.1., Cui W., Li X., Jin Y. (2008) Electrospun fibrous mats with high porosity as potential scaffolds for skin tissue engineering. Biomacromolecules. 9 (7): 1795-1801. 